„FOLIA BIBLIOLOGICA” (2018), VOL. LX

DOI: $10.17951 / \mathrm{fb} .2018 .60 .99-110$

\author{
Magdalena Cyrklaff-Gorczyca \\ Instytut Informacji Naukowej i Bibliologii \\ Uniwersytet Mikołaja Kopernika w Toruniu \\ https://orcid.org/0000-0002-4062-1966
}

\title{
MEDIA RELATIONS WYBRANYCH BIBLIOTEK TORUŃSKICH. CELE, NARZĘDZIA I PLANY ROZWOJU
}

\begin{abstract}
Streszczenie: Budowanie pozytywnego wizerunku biblioteki w środowisku lokalnym wymaga znajomości i systematycznego wdrażania elementów public relations. Jednym z etapów tego działania są media relations, czyli utrzymywanie dobrych stosunków z przedstawicielami mediów, co może wpływać pozytywnie na odbiór organizacji w otoczeniu społecznym. W artykule przedstawiono analizę działań w ramach media relations trzech największych toruńskich bibliotek: Biblioteki Pedagogicznej im. gen. bryg. prof. Elżbiety Zawackiej, Biblioteki Uniwersytetu Mikołaja Kopernika oraz Wojewódzkiej Biblioteki Publicznej - Książnicy Kopernikańskiej. Wykorzystano do tego metodę sondażu diagnostycznego oraz analizę treści stron internetowych badanych bibliotek. Biblioteka uniwersytecka i publiczna są dobrze przygotowane i prężnie działają $\mathrm{w}$ zakresie promocji, jednak utożsamiają to pojęcie z public relations i nie rozdzielają tych zagadnień w praktyce, natomiast biblioteka pedagogiczna nie ma sekcji ds. promocji i PR, ale zadanie utrzymywania kontaktu z mediami należy do jednego z pracowników. Żadna z bibliotek nie wykorzystuje w pełni możliwości, jakie daje posiadanie strony internetowej.
\end{abstract}

Słowa kluczowe: media relations, public relations, promocja, komunikacja społeczna, biblioteka uniwersytecka, biblioteka publiczna, biblioteka pedagogiczna

\section{Media Relations of Selected Toruń Libraries. Objectives, Tools and Development Plans}

Abstract: Building a positive image of a library in a local environment requires familiarity and systematic implementation of public relations elements. One of them is media relations, or maintaining good relations with representatives of the media, which may have a positive impact on the reception of the organization in the social environment. The article presents an analysis of media relations activities of the three largest libraries in Toruń: the Pedagogical Library of Brig. Gen. Prof. Elżbieta Zawacka, the University Library of the Nicolaus Copernicus University and the Provincial Public Library - Copernicus Library. A method of the research was a diagnostic survey and an analysis of the content of the websites of the examined libraries. The university and 
public library are well prepared and thriving in the field of promotion, however, they equate this concept with public relations and do not separate these issues in practice, while the pedagogical library does not have a promotion and PR section, but the task of maintaining contact with the media belongs to one of the employees. Each library does not make full use of the possibilities offered by having a website.

Keywords: media relations, public relations, promotion, social communication, university library, public library, pedagogical library

\section{Wprowadzenie}

Wraz z wkroczeniem w XXI wiek i eksplozją rozwoju technologii informacyjno-komunikacyjnych biblioteki stanęły przed nowymi wyzwaniami i zagrożeniami. Wśród zadań pojawiły się głównie te związane z próbą organizacji coraz większych ilości danych i informacji, ujednoliceniem opisu obiektów cyfrowych i zarządzaniem nimi czy też przeniesieniem punktu ciężkości pracy bibliotekarza z pracy „analogowej” na pracę zinformatyzowaną. Może to być zarówno wyzwaniem, jak i pewnym zagrożeniem związanym z rozluźnieniem relacji z czytelnikiem, który jeszcze dekadę temu pojawiał się w bibliotece na dłużej niż tylko moment odbioru zamówionej elektronicznie książki. Biblioteki ewoluują współcześnie w stronę centrów informacji, mediatek, co z jednej strony jest wielkim krokiem naprzód, a z drugiej może budzić lęk wśród pracowników i tęsknotę za tym, co było kiedyś. Istotne $\mathrm{w}$ procesie tych zmian jest jednak to, aby prowadzić aktywny dialog z instytucjami i przedstawicielami otoczenia społecznego biblioteki, co pozwoli na zbudowanie pozytywnego wizerunku tej placówki w środowisku lokalnym i przyciągnięcie do niej większej liczby czytelników. Biblioteka jako organizacja non-profit nie dysponuje środkami przeznaczonymi na reklamę i intensywną strategię promocyjną, zatem najważniejszą metodą działań służących pozytywnej komunikacji i współpracy z otoczeniem będzie public relations (dalej: PR). PR „to świadome, planowe i ciągłe wysiłki, mające na celu ustanowienie i utrzymanie wzajemnego zrozumienia między daną organizacją a jej otoczeniem"'. Niektórzy badacze utożsamiają PR, w szczególności ten realizowany przez organizacje non-profit, z komunikacją, aby podkreślić jego neutralny charakter i odróżnić od spotykanych w literaturze przedmiotu pejoratywnych określeń (np. PR jako kosztowny dodatek do działalności organizacji; działanie moralnie ambiwalentne $)^{2}$. I w ten sposób - czyli jako proces

1 J. Crisford, Public relations. Advances, London 1974, s. 3; cyt. za: W. Budzyński, Public relations. Zarzadzanie reputacja firmy, Warszawa 2001, s. 10.

${ }_{2}$ M. Łukasiuk, PR NGOsów. Komunikacja strategiczna organizacji pozarzadowych, Warszawa 2014, s. 3 . 
komunikowania się z bliższym lub dalszym otoczeniem w celu pielęgnowania relacji - może być pojmowany PR bibliotek.

Do kształtowania dobrych relacji z otoczeniem wykorzystuje się w ramach działań public relations między innymi następujące działania:

- media relations - współpracę z mediami;

- corporate identity - elementy kształtujące tożsamość organizacji;

- lobbing - „każde działanie prowadzone metodami prawnie dozwolonymi zmierzające do wywarcia wpływu na organy władzy publicznej w procesie stanowienia prawa"3;

- sponsoring - „działanie marketingowe, promujące firmę, usługę lub produkt, w związku z wizerunkiem czy prestiżem, które ma przynieść określone korzyści sponsorowi"4;

- zarządzanie sytuacją kryzysową organizacji;

- druki/wydawnictwa własne organizacji;

- public affairs - tworzenie pozytywnych relacji z przedstawicielami władzy (np. lokalnej, regionalnej lub krajowej);

- community relations - tworzenie pozytywnych relacji ze społecznościami lokalnymi ${ }^{5}$.

Na potrzeby niniejszego artykułu scharakteryzowano media relations, które były przedmiotem badań w toruńskich bibliotekach.

\section{Istota media relations}

„Media to termin oznaczający prasę, radio i telewizję jako tzw. media masowe, to znaczy instytucje produkujące przekazy informacyjne i rozrywkowe rozpowszechniane masowo i docierające jednocześnie do wielkich, rozproszonych zbiorowości

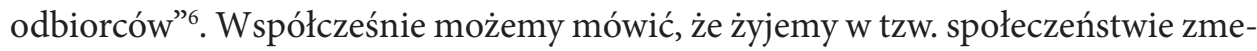
diatyzowanym, w którym życie ludzkie jest do tego stopnia nasycone mediami, że jest aż od nich zależne ${ }^{7}$. Media masowe są obecnie:

3 Ustawa z dnia 7 lipca 2005 r. o działalności lobbingowej w procesie stanowienia prawa, Dz. U. 2005, Nr 169, poz. 1414, s. 1.

4 A. Góźdź, Sponsoring - czyżby 5 element promocji-mix?, „Zeszyty Naukowe Wyższej Szkoły Ekonomiczno-Społecznej w Ostrołęce" 2009, s. 35.

${ }_{5}$ W. Budzyński, op. cit., s. 11; D. Kuźma, K. Armatys, Public relations, [w:] Encyklopedia zarządzania [online]. Dostępny w World Wide Web: https://mfiles.pl/pl/index.php/Public_relations, [dostęp: 05.01.2018].

6 T. Goban-Klas, Media i medioznawstwo, [w:] Słownik wiedzy o mediach, red. E. Chudziński, Warszawa-Bielsko-Biała 2007, s. 9.

7 Ibidem, s. 17. 
- jednym z najpotężniejszych instrumentów władzy społecznej;

- narzędziem kontroli społecznej;

- źródłem informacji i powstawania innowacyjnych rozwiązań;

- otwartym, ogólnodostępnym forum życia publicznego i politycznego;

- miejscem narodzin gwiazd i osób wpływowych;

- podstawowym źródłem definiowania rzeczywistości społecznej;

- źródłem systemu znaczeń, który dostarcza kryteriów do osądzania8.

Dewizą wielu dziennikarzy jest maksyma „bad news is a good news”, dlatego w szczególności organizacje użyteczności publicznej - szkoły, uczelnie wyższe, instytucje kultury ( $w$ tym biblioteki), instytucje służby zdrowia, samorządy czy też służby mundurowe powinny mieć jasno określoną strategię public relations, a w niej media relations. Media relations organizacji to stałe i częste utrzymywanie kontaktów z mediami w celu zainteresowania bliskiego i dalszego otoczenia jej działalnością oraz wykreowanie jej pozytywnego wizerunku i opinii w społeczności9

Do podstawowych metod współpracy bibliotek z mediami najczęściej zalicza się:

- przekazywanie informacji prasowych (np. bieżące informacje prasowe, oświadczenia prasowe, opracowania specjalistyczne, materiały gotowe do publikacji, teksty/artykuły sponsorowane);

- odpowiedzi na zapytania mediów;

- organizowanie konferencji prasowych;

- udzielanie wywiadów ${ }^{10}$.

Ponadto mogą to być jeszcze:

- zapraszanie dziennikarzy na uroczystości - w szczególności imprezy organizowane w ramach Tygodnia Bibliotek, Nocy Bibliotek, Światowego Dnia Książki, wizyty znanego pisarza itp. ${ }^{11}$;

- programy telewizyjne/radiowe dotyczące bibliotek - realizowane w szczególności przez telewizje/stacje regionalne, np. 19 maja 2017 r. w programie „Akcja Innowacja” w TVP 3 Bydgoszcz dyskutowano o przyszłości i zmianach w bibliotekach. Na stronie internetowej programu można przeczytać, że „nowatorskie rozwiązania nie muszą nieść ze sobą rewolucji i pochłaniać fortuny. Innowacje to także zmiany, jakie zachodzą w kontaktach między ludźmi i w ich mentalności. Dzięki budowaniu tych relacji tworzą się nowe idee, postawy, praktyki i pomysły na to, jak efektyw-

${ }^{8}$ Ibidem, s. 10. Por. z I. Schenkler, T. Herrling, Relacje $z$ mediami, tłum. M. Werbanowska, Warszawa 2009, s. 13-14, 16-21.

9 Zob. M. Wojciechowska, Media relations jako forma komunikacji marketingowej biblioteki, „Toruńskie Studia Bibliologiczne” 2009, nr 2 (3), s. 81.

${ }_{10}$ Ibidem, s. 84-87.

11 Zob. np. Master TV Łuków - Tydzień bibliotek [online]. Dostępny w World Wide Web: https://www.youtube.com/watch?v=Ll0E2flGBgw [dostęp: 22.12.2017]. 
nie zaspokajać potrzeby społeczne. Jak to robić? W programie "Akcja Innowacja« spróbujemy odpowiedzieć na to pytanie"12;

- relacje telewizyjne/radiowe z eventu bibliotecznego - realizowane w szczególności przez telewizje/stacje lokalne, które zwykle są zainteresowane wydarzeniami organizowanymi przez biblioteki dla mieszkańców danej miejscowości ${ }^{13}$;

- relacje internetowe na żywo z eventu bibliotecznego - powinny się stać coraz bardziej powszechne ze względu na bezpłatną formę kanału live, np. na portalu Facebook;

- stała rubryka poświęcona bibliotece w gazecie lokalnej - w szczególności jeśli to mała miejscowość i współpraca z mediami jest bardzo dobra i regularna.

Oprócz tradycyjnych/podstawowych form współpracy bibliotek z mediami warto zwrócić uwagę na te zaproponowane tuż po nich. Stanowią one przykłady działań, które angażują dziennikarzy bezpośrednio w przygotowywanie materiału o lub dla biblioteki, do czego jest potrzebna współpraca z bibliotekarzami, co stanowi szansę na zapoznanie się z dziennikarzami osobiście i dalszą kooperację.

$\mathrm{O}$ to, jak wyglądają relacje/współpraca z mediami, zapytano dyrekcje trzech największych bibliotek w Toruniu. Wyniki tej diagnozy przedstawiono w dalszej części artykułu.

\section{Metodologia badań}

Celem badań było sprawdzenie, jak kształtują się relacje z mediami trzech największych bibliotek w Toruniu: Biblioteki Pedagogicznej im. gen. bryg. prof. E. Zawackiej (dalej: Biblioteka Pedagogiczna, BP), Biblioteki Uniwersytetu Mikołaja Kopernika w Toruniu (dalej: Biblioteka Uniwersytecka, BUMK) oraz Wojewódzkiej Biblioteki Publicznej - Książnicy Kopernikańskiej (dalej: WBPKK, Książnica Kopernikańska, KK). Badanie miało wykazać, czy biblioteki te projektują swoje działania public relations oraz wprowadzają udoskonalenia, w szczególności w zakresie media relations.

Jako metodę badawczą wykorzystano sondaż diagnostyczny, ponieważ jest to sposób gromadzenia wiedzy o cechach strukturalnych i funkcjonalnych oraz dynamice zjawisk i opiniach o nich zarówno większej społeczności, jak i pojedynczych jednostek $^{14}$. Dzięki sondażowi stosunkowo łatwo było uchwycić kierunek rozwoju

${ }_{12}$ Akcja Innowacja - TVP3 Bydgoszcz - Telewizja Polska S.A., [online]. Dostępny w World Wide Web: http://bydgoszcz.tvp.pl/27055494/akcja-innowacja [dostęp: 22.12.2017].

13 Zob. np. Radio 90 na czytelniczym happeningu w Cieszynie, [online]. Dostępny w World Wide Web: https://www.youtube.com/watch?v=mlakVjM9KAg [dostęp: 22.12.2017].

${ }_{14}$ T. Pilch, T. Bauman, Zasady badań pedagogicznych. Strategie ilościowe i jakościowe, Warszawa 2001, s. 80 . 
działań bibliotek z zakresu public i media relations. Dokonano także analizy materiałów źródłowych, stron internetowych i znajdujących się na nich informacji skierowanych do prasy oraz innych zainteresowanych.

W badaniach posłużono się techniką ankietową, w której wykorzystano specjalnie na ten cel przygotowane narzędzie w postaci kwestionariusza ankiety. Składał się on z dziesięciu pytań zamkniętych, dziewięciu pytań otwartych i miejsca na uwagi respondenta. Początkowe pytania dotyczyły tego, czy w bibliotece istnieje jednostka ds. promocji i/lub public relations, ile osób jest w niej zatrudnionych, jaki jest zakres ich obowiązków oraz czy zatrudniony jest tam rzecznik prasowy. Następnie zapytano o to, czy w bibliotece pracuje osoba odpowiedzialna wyłącznie za kontakty z mediami, czy pracownik ten został przeszkolony w zakresie redagowania informacji dla prasy i kontaktów z mediami, a także jakie instrumenty są wykorzystywane w bibliotece do kontaktu z mediami oraz czy w placówce istnieje opracowana i sukcesywnie wdrażana strategia komunikacji z mediami i otoczeniem. Kolejnym krokiem było pytanie o to, czy kontakt z mediami w danej placówce wymusza najczęściej bieżąca emocjonująca opinię publiczną sytuacja (np. gdy odkryto w zbiorach jednej z bibliotek książki oprawione w ludzką skórę), w jaki sposób biblioteka nawiązuje kontakty z mediami, z którymi z nich kontaktuje się najczęściej i dlaczego, czy organizuje imprezy dedykowane mediom w celu zaznajomienia ich z planami, usługami i przedsięwzięciami biblioteki oraz czy organizuje konferencje prasowe. Zapytano także o to, czy pracownicy biblioteki udzielają często wywiadów lokalnym mediom, czy biblioteka dostaje zapytania od mediów, prośby o komentarze oraz jakie materiały placówka przekazuje mediom najczęściej. Dwa ostatnie pytania dotyczyły tego, czy w bibliotece jest stosowany monitoring mediów oraz badanie odbioru jej wizerunku w mediach i otoczeniu społecznym.

Badania przeprowadzono na początku października 2017 r. Ankiety przesłano wtedy do dyrektorów bibliotek drogą e-mailową. Wszyscy dyrektorzy z chęcią wzięli udział w badaniach, przekierowując ankietę do pracownika odpowiedzialnego za prowadzenie działań związanych z jej tematyką.

\section{Wyniki badań}

Jednostka ds. promocji i/lub public relations funkcjonuje w bibliotece uniwersyteckiej i książnicy miejskiej. W pierwszej z nich są zatrudnione cztery osoby, a w drugiej dwie (kierownik samodzielnej sekcji ds. promocji oraz specjalista ds. promocji). Osoby zatrudnione w tych bibliotekach $w$ ramach swoich działań promocyjnych są odpowiedzialne za kontakt $\mathrm{z}$ mediami i zostały do tego przeszkolone. Sekcje dbają o stały kontakt z mediami: w bibliotece publicznej co 2-3 dni, 
a w uniwersyteckiej rzadziej. Kontakt ten to raczej promowanie oferty biblioteki i wydarzeń niż pogłębianie relacji i kontaktów z przedstawicielami mediów. Zapytania od mediów, prośby o komentarze pojawiają się zwykle samoistnie, głównie w okresie np. obchodów Dnia Książki. Współpraca z mediami tych instytucji także ma raczej charakter reaktywny.

W zakres obowiązków sekcji ds. promocji w książnicy wchodzi:

- „obsługa mediów (inicjowanie i utrzymywanie kontaktów z dziennikarzami, przygotowywanie informacji i innych materiałów prasowych, udzielanie wywiadów, umawianie wywiadów z innymi pracownikami Książnicy Kopernikańskiej);

- poszukiwanie nowych kanałów komunikacji;

- monitorowanie mediów (kto, co i ile napisał/powiedział o Książnicy Kopernikańskiej);

- obsługa mediów społecznościowych (komunikacja na Facebooku i Twitterze);

- wysyłanie informacji prasowych do mediów tradycyjnych oraz serwisów i portali internetowych;

- samodzielne publikowanie informacji prasowych w serwisach i portalach internetowych;

- publikowanie informacji na stronie internetowej Książnicy Kopernikańskiej;

- direct mailing (wysyłanie informacji do zainteresowanych osób i instytucji);

- crossowanie informacji w mediach społecznościowych (wymiana informacji $\mathrm{z}$ innymi instytucjami kultury posiadającymi profile na $\mathrm{FB}$ );

- pozyskiwanie do współpracy partnerów, którzy mogą pomóc w promocji wydarzeń, np. samorząd studencki UMK;

- projektowanie materiałów promocyjnych (plakaty, ulotki, zaproszenia, grafiki do mediów społecznościowych i na stronę Książnicy Kopernikańskiej);

- druk i dystrybucja materiałów promocyjnych (głównie plakatowanie przestrzeni publicznej w mieście);

- przygotowywanie relacji fotograficznych z wydarzeń organizowanych przez KK;

- organizacja i obsługa imprez;

- współpraca z innymi instytucjami i organizatorami imprez, np. Dworem Artusa, Coperniconem, Klubem Sobótka (wspólne przygotowywanie wydarzeń)"15.

Z kolei do zakresu działań pracowników sekcji promocji w BUMK należy:

- prowadzenie kalendarza wydarzeń w BU;

${ }^{15}$ Cytat pochodzi z ankiety przesłanej przez pracownika Książnicy Kopernikańskiej w Toruniu. W dalszej części artykułu wypowiedzi zaznaczone cudzysłowem i przypisane do danej biblioteki będą oznaczały wypowiedź jej pracownika w ankiecie. 
- prace organizacyjno-techniczne przy organizacji przedsięwzięć: zapewnienie miejsca oraz sprzętu do realizacji przedsięwzięcia, instalacja ekspozycji itp. (współpraca z Oddziałem Administracyjno-Gospodarczym);

- zapewnienie sprzętu audiowizualnego i nagłaśniającego oraz obsługi fotograficznej i nagrań audio-wideo (współpraca z Oddziałem Komputeryzacji i Digitalizacji);

- sporządzanie list adresowych zapraszanych gości oraz projektowanie i dystrybucja zaproszeń;

- projektowanie oraz wydruk folderów i plakatów promujących wydarzenia;

- informowanie społeczności akademickiej oraz mieszkańców regionu o imprezach za pośrednictwem poczty elektronicznej oraz uczelnianych i regionalnych mediów, a także portalu kulturawzasiegu.pl, systemu elektronicznego plakatu, strony WWW BU i UMK, portali społecznościowych (Facebook, Pinterest, Twitter, Google+, You Tube)".

Jak widać, obie biblioteki prowadzą intensywne i wielokanałowe działania informacyjne i promocyjne, które dotyczą imprez i innych realizowanych przez nie działań. Warto zaznaczyć, że pracownicy sekcji promocji z Biblioteki Uniwersyteckiej podkreślili w swojej wypowiedzi w ankiecie współpracę z innymi działami biblioteki (np. Administracyjno-Gospodarczym i Komputeryzacji i Digitalizacji), których wsparcie techniczne jest niezbędne do realizacji imprez i obsługi fotograficznej oraz audio-wideo.

Biblioteka Pedagogiczna nie posiada w swojej strukturze wydzielonej sekcji promocji/public relations, jednak pracownik tej placówki wskazał w ankiecie, że w bibliotece jest zatrudniona osoba odpowiedzialna za kontakt z mediami, która została do tego przeszkolona.

Zarówno Książnica Kopernikańska, jak i Biblioteka Uniwersytecka i Biblioteka Pedagogiczna stosują standardowe narzędzia współpracy z mediami, jak komunikaty i wywiady. KK stara się wykorzystywać wszystkie dostępne narzędzia i metody do wspomnianych wywiadów, dołączając jeszcze: informacje prasowe i rzadziej konferencje prasowe. Biblioteka Pedagogiczna wysyła także zaproszenia, zwraca się z prośbą o objęcie przedsięwzięcia patronatem medialnym.

Wszyscy respondenci zgodnie stwierdzili, że ich placówka ma opracowaną wcześniej i wdrażaną systematycznie strategię komunikacji z mediami i otoczeniem. KK nawiązuje kontakt $\mathrm{z}$ mediami „za pośrednictwem wszystkich dostępnych środków i kanałów dystrybucji informacji. Na pierwszym miejscu są osobiste relacje z dziennikarzami (telefon, mail) - kontakt aktywny ( $\mathrm{z}$ inicjatywą wychodzą pracownicy sam. sekcji ds. promocji). W dalszej kolejności (kontakt pasywny) - informacje na stronie internetowej Książnicy Kopernikańskiej oraz w mediach społecznościowych". W podobny sposób działają pracownicy sekcji promocji BUMK oraz Biblioteki Pedagogicznej. 
Jeśli chodzi o media, z którymi najczęściej współpracują badane biblioteki, to w wypowiedziach respondentów pojawiały się zarówno wspólne tytuły, jak i inne. Przykładowo pracownik KK wypowiedział się na ten temat w ten sposób: „Korzystamy z pomocy wszystkich mediów, w zależności od tego, do kogo adresujemy wydarzenie, np. aby dotrzeć z informacją do użytkowników w wieku 40+ konieczna będzie publikacja w »Nowościach«. Tutaj tendencja »konsumowania« mediów przez naszych użytkowników jest dość wyraźna - młodzi ludzie szukają informacji w Internecie, starsi są przyzwyczajeni do tradycyjnych form komunikowania (prasa, radio, telewizja). Założenie jest takie, że staramy się być wszędzie tam, gdzie są nasi użytkownicy”. Z kolei pracownik BUMK opisał to tak: „Nowości: „Dziennik Toruński«, »Toruński Informator Kulturalno-Artystyczny IKAR«, Telewizja Kablowa Toruń, TV UMK, Radio Sfera - te media są zainteresowane wydarzeniami w bibliotece, pozytywnie odpowiadają na zaproszenia”. W przypadku Biblioteki Pedagogicznej pojawiają się takie tytuły: „Najczęściej kontaktujemy się z mediami regionalnymi - prasa: »Nowości«, »Gazeta Wyborcza«, »Gazeta Pomorska«, telewizja: Telewizja Kablowa Toruń, „Zbliżenia«, Telewizja internetowa UMK, radio: Radio Gra, Radio Pik, Radio Eska, Radio Sfera, informatory kulturalne: »Ikar«, »Biuletyn Informacji Kulturalnej Wojewódzkiego Ośrodka Animacji Kultury«, serwisy internetowe: Serwis Toruński, Kulturalny Toruń. Wydarzenia organizowane w naszej placówce najczęściej są adresowane do mieszkańców naszego regionu i media regionalne pomagają nam dotrzeć do nich. Jeśli przygotowujemy wydarzenia o zasięgu ogólnopolskim (np. konferencje, uroczystości związane ze świętem naszej Biblioteki), wtedy zawiadamiamy też media ogólnopolskie: Telewizja TVN, czasopisma branżowe: »Poradnik Bibliotekarza«, »Bibliotekarz«, serwis Elektroniczna Biblioteka Pedagogiczna SBP”. Biblioteka Pedagogiczna, jak widać, stawia także na informowanie mediów ogólnopolskich, co jest szczególnie wartościowe, jeśli chodzi o imprezy o wysokim walorze innowacyjności, na przykład w zakresie edukacji, bo jak wiadomo, jednym z głównych działań BP jest wspieranie rozwoju nauczycieli i warsztatu ich pracy.

Respondenci zgodnie odpowiadali, że nie organizowali do tej pory konferencji prasowych, zaś w BUMK takie działanie jest w planach. Ponadto żadnej z badanych bibliotek nie zdarzyło się do tej pory wysyłać oświadczeń do mediów oraz, ze względu na brak środków, tekstów sponsorowanych. Każda z bibliotek przesyłała głównie bieżące informacje prasowe (co kilka dni), teksty promujące czytelnictwo (przy okazji imprez branżowych typu Światowy Dzień Książki i Praw Autorskich itp.) oraz rzadziej opracowania specjalistyczne.

$\mathrm{W}$ przedostatnim pytaniu zapytano o to, czy biblioteka analizuje publikowane na jej temat w mediach informacje i zbiera dane o ich odbiorcach, czyli czy wykonuje swoisty monitoring mediów. Biblioteka Pedagogiczna nie podejmuje takich działań, 
Biblioteka Uniwersytecka robi to okazjonalnie i tylko dla wybranych tytułów, zaś Książnica Kopernikańska wykonuje to regularnie.

Ostatnie pytanie dotyczyło badania wizerunku w mediach i otoczeniu społecznym - tutaj BUMK i BP wskazały, że nie podejmują takich wysiłków, zaś KK ujęła to w taki sposób: „Formą takiego badania jest bieżący monitoring mediów - na podstawie relacji i doniesień prasowych, radiowych, telewizyjnych, internetowych oceniamy kontekst, w jakim Książnica Kopernikańska została opisana. Zwracamy również uwagę na komentarze w mediach społecznościowych. Reagujemy na bieżąco".

Żaden $\mathrm{z}$ respondentów nie wpisał w kwestionariuszu uwag do badania czy narzędzia badawczego.

\section{Podsumowanie}

Badania ukazały inicjatywy i starania oraz pewne luki w działaniach z zakresu media relations wybranych toruńskich bibliotek. Oprócz badania ankietowego prześledzono także treści publikowane na stronach WWW badanych placówek, zwracając głównie uwagę na elementy media relations oraz dopasowanie treści i profilu działań do głównych klientów tych bibliotek. Do pozytywnych wniosków z badań należą niewątpliwie m.in. takie:

- biblioteka uniwersytecka i publiczna są dobrze przygotowane i prężnie działają $\mathrm{w}$ zakresie promocji, jednak utożsamiają to pojęcie z public relations i nie rozdzielają tych zagadnień w praktyce;

- biblioteka pedagogiczna nie ma sekcji ds. promocji i PR, ale zadanie utrzymywania kontaktu z mediami należy do jednego z pracowników;

- wszystkie $\mathrm{z}$ badanych bibliotek wykorzystują $\mathrm{w}$ ramach media relations: notatki prasowe, wywiady, materiały specjalne/dedykowane/informacyjne, relacje, a więc głównie podstawowe instrumenty kontaktu z mediami.

Do pewnych luk w kontaktach z mediami, a w niektórych kwestiach nawet negatywnych wniosków, można zaliczyć to, że:

- BUMK i BP nie badają odbioru ich wizerunku w mediach i otoczeniu społecznym, a więc raczej nie są zainteresowane opiniami klientów, tylko realizacją swoich założeń promocyjnych;

- po analizie treści dostępnych na stronie internetowej biblioteki naukowej widać, że nie wykorzystuje ona w wystarczającym stopniu współpracy ze środowiskiem studentów, które jest jedną z jej głównych grup odbiorców (np. brak działań/ imprez dedykowanych tej grupie czytelników);

- na stronach WWW biblioteki PED i PUB nie ma zakładki „dla mediów”; 
- na stronie internetowej biblioteki uniwersyteckiej istnieje zakładka „o bibliotece” $\rightarrow$, a dalej odnośnik „dla mediów” $\rightarrow$ i następnie „informacje dla mediów” $\rightarrow$, jednak ostatnia aktualizacja tych informacji odbyła się 16 stycznia 2014 roku. W tym aspekcie zatem wszystkie $\mathrm{z}$ badanych bibliotek mogłyby dokonać zmian.

Public i media relations to bardzo przystępne i tanie (czasem nawet bezpłatne) formy oddziaływania na potencjalnych odbiorców usług i działań bibliotek, z których jednak trzeba umiejętnie korzystać. Wydaje się, że największym problemem w tym zakresie, jeśli chodzi o badane biblioteki, jest rozumienie istoty tych działan i nieutożsamianie ich z promocją czy reklamą, a także dbanie o bieżące monitorowanie mediów i badanie odbioru wizerunku. Do tego może czasami wystarczyć udział w szkoleniu i zapoznanie się z podręcznikami i dobrymi praktykami w tym zakresie, także na gruncie międzynarodowym ${ }^{16}$.

\section{Bibliografia}

Akcja Innowacja - TVP3 Bydgoszcz - Telewizja Polska S.A., [online]. Dostępny w World Wide Web: http://bydgoszcz.tvp.pl/27055494/akcja-innowacja [dostęp: 22.12.2017].

Budzyński W., Public relations. Zarzadzanie reputacja firmy, Warszawa 2001.

Goban-Klas T., Media i medioznawstwo, [w:] Stownik wiedzy o mediach, red. E. Chudziński, Warszawa-Bielsko-Biała 2007, s. 9-20.

Góźdź A., Sponsoring - czyżby 5 element promocji-mix?, „Zeszyty Naukowe Wyższej Szkoły Ekonomiczno-Społecznej w Ostrołęce" 2009, s. 35-38.

Kuźma D., Armatys K., Public relations - Encyklopedia zarządzania, [online]. Dostępny w World Wide Web: https://mfiles.pl/pl/index.php/Public_relations [dostęp: 05.01.2018].

Łukasiuk M., PR NGOsów. Komunikacja strategiczna organizacji pozarzadowych, Warszawa 2014.

Master TV Łuków - Tydzień bibliotek, [online]. Dostępny w World Wide Web: https://www. youtube.com/watch?v=Ll0E2flGBgw [dostęp: 22.12.2017].

Media relations. Handbook for libraries, [online]. American Library Association. Dostępny w World Wide Web: http://www.ala.org/advocacy/sites/ala.org.advocacy/files/content/ ALA-Media-Relations-Handbook.pdf [dostęp: 05.01.2018].

Partnerzy bibliotek. Model komunikacji z otoczeniem, red. I. Jurczak, E. Okularczyk, Łódź 2008.

${ }_{16}$ Zob. np. M. Łukasiuk, PR NGOsów...; Media relations. Handbook for libraries, [online]. American Library Association. Dostępny w World Wide Web: http://www.ala.org/advocacy/sites/ ala.org.advocacy/files/content/ALA-Media-Relations-Handbook.pdf [dostęp: 05.01.2018]. Partnerzy bibliotek. Model komunikacji z otoczeniem, red. I. Jurczak, E. Okularczyk, Łódź 2008; P. Sanowski, Nowoczesny monitoring mediów, [w:] Public relations instytucji użyteczności publicznej, red. E. Hope, Gdańsk 2005, s. 55-63. 
Pobrane z czasopisma Folia Bibliologica http:/foliabibliologica.umcs.pl

Data: 26/04/2023 02:30:17

Radio 90 na czytelniczym happeningu w Cieszynie, [online]. Dostępny w World Wide Web: https://www.youtube.com/watch?v=mlakVjM9KAg [dostęp: 22.12.2017].

Sanowski P., Nowoczesny monitoring mediów, [w:] Public relations instytucji użyteczności publicznej, red. E. Hope, Gdańsk 2005, s. 55-63.

Schenkler I., Herrling T., Relacje z mediami. Przewodnik, tłum. M. Werbanowska, Warszawa 2009.

Taktyka i narzędzia PR, [online]. Dostępny w World Wide Web: http://www.promujngo. com/strategia-pr-dla-ngo/taktyka-i-narzdzia-pr [dostęp: 22.12.2017].

Ustawa z dnia 7 lipca 2005 r. o działalności lobbingowej w procesie stanowienia prawa, Dz.U. 2005, Nr 169, poz. 1414.

Wojciechowska M., Media relations jako forma komunikacji marketingowej biblioteki, „Toruńskie Studia Bibliologiczne" 2009, nr 2 (3), s. 81-91, DOI: http://dx.doi.org/10.12775/ TSB.2009.020. 